\title{
ЭТИОПАТОГЕНЕТИЧЕСКИЕ АСПЕКТЫ ФУРУНКУЛА ЧЕЛЮСТНО-ЛИЦЕВОЙ ОБЛАСТИ (ОБЗОР ЛИТЕРАТУРЫ)
}

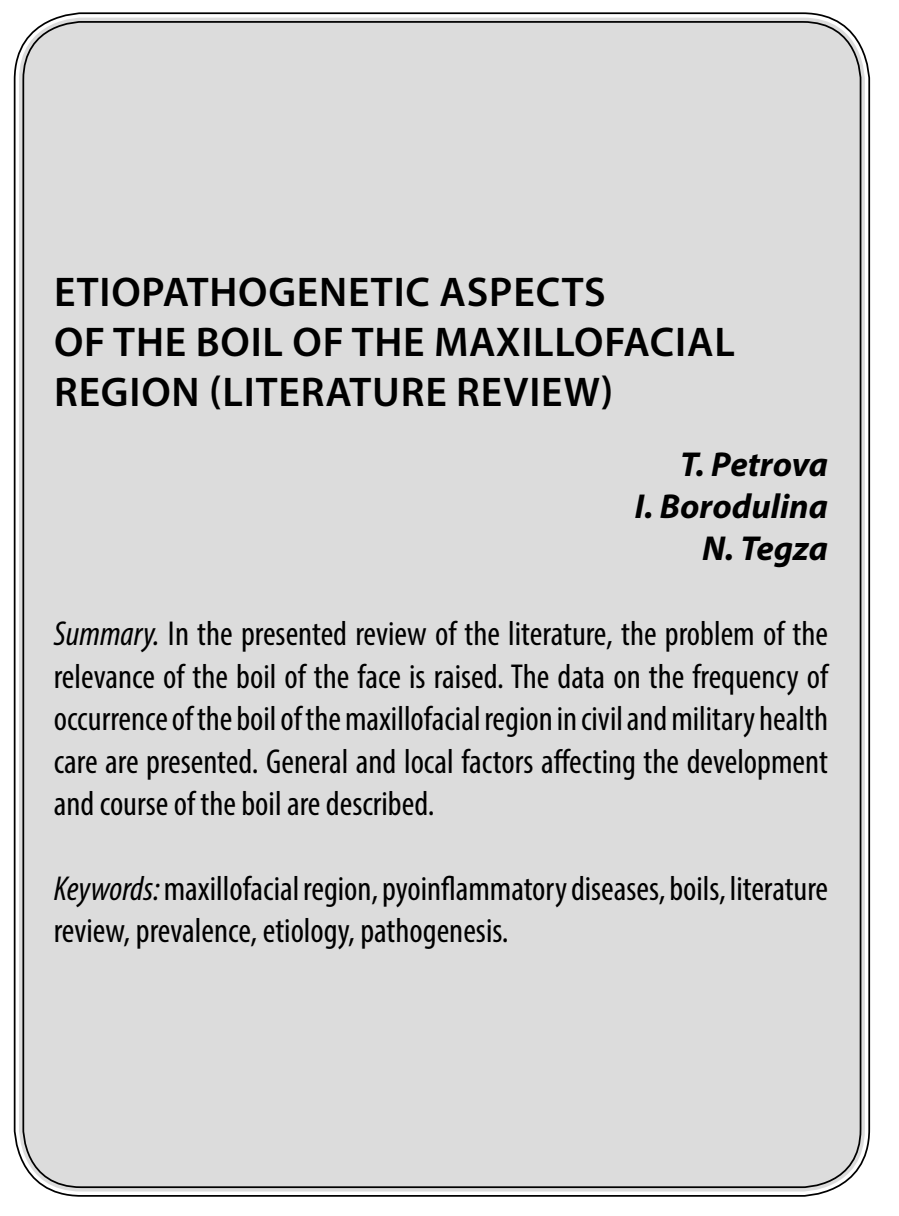

$\mathbf{B}$ настоящее время наблюдается тенденция сохранения высокого числа пациентов с гнойно-воспалительными заболеваниями. При анализе их локализации в области головы и шеи, установлено, что наряду с увеличением числа одонтогенных гнойно-воспалительных процессов происходит рост бактериальных инфекций кожи. Из числа последних одним из наиболее часто встречающихся является фурункул челюстно-лицевой области.

Фурункул - острое гнойно-некротическое воспаление волосяного фолликула, сальной железы и окружающих его тканей. По данным различных источников в нашей стране в общей структуре оказания медицинской помощи больным в лечебно-профилактических учреждениях стационарного профиля заболеваемость фурункулом челюстно-лицевой составляет до $30 \%$, из которых 20\% случаев характеризуются осложненным течением (тромбофлебит лицевой вены, сепсис, абсцесс, флегмо-
Петрова Татьяна Вячеславовна Аспирант, Военно-Медицинская Академия им. С.М. Кирова, Санкт-Петербург

tanya-petrova-1995@yandex.ru Бородулина Ирина Ивановна Д.м.н., профессор, Военно-Медицинская Академия им. С.М. Кирова, Санкт-Петербург borodulina59@mail.ru

Тегза Николай Васильевич К.м.н., доцент, Военно-Медицинская Академия им. С.М. Кирова, Санкт-Петербург tegza75@mail.ru

Аннотация. В представленном обзоре литературы поднимается проблема актуальности фурункула лица. Представлены данные о частоте встречаемости фурункула челюстно-лицевой области в гражданском и военном здравоохранении. Описаны общие и местные факторы, влияющие на развитие и течение фурункула.

Ключевые слова: челюстно-лицевая область, гнойно-воспалительные заболевания, фурункулы, обзор литературы, распространенность, этиология, патогенез.

на, синус-тромбоз.). От общего числа пациентов с воспалительными заболеваниями челюстно-лицевой области фурункул лица составляет от 10 до 20\% [6, 14, 16, 35, 36, 41].

Гнойно-воспалительные заболевания мягких тканей в Вооруженных Силах РФ также представляют собой важную проблему, поддерживающую высокий уровень заболеваемости. В структуре сформированного обобщенного показателя нарушений здоровья военнослужащих актуальным остаются болезни кожи и подкожной клетчатки (XII класс) - 7\% от общей структуры нарушений здоровья военнослужащих по призыву (87\%) [1, 7, $10,25]$.

Изучением гнойно-воспалительных заболеваний мягких тканей в Вооруженных силах РФ занимались И.Ю. Быков, А.В. Самцов, В.В. Гладько, М.В. Устинов (2006). Согласно их исследованиям, у военнослужащих по при- 
зыву доля таких заболеваний составляет более четверти, а в отдельных видах, родах войск и военных округах более трети всей заболеваемости по ВС [7].

История развития взглядов на этиопатогенез и принципы лечения пиодермий содержит многие интересные факты.

Гиппократ первым сформулировавший такие понятия, как «заживление раны без полости», «заживление ран с нагноением», описал клинику флегмоны, абсцесса, карбункула, а также выдвинул основной принцип их лечения — «ubi pue, ibi evacua» — «где [есть] гной, там эвакуируйте [это]» $[8,28]$.

Древние египтяне за 3000 лет до н.э. использовали для лечения гнойных заболеваний кожи мед, масло, вино.

В Средние века в лечении пиодермии использовали мази из скипидара, розового масла, яичных желтков, применяли сулему.

B XVII - XIX века в качестве антисептических средств для местного лечения воспалительных процессов кожи врачи применяли карболовую, борную кислоты, ксероформ, йодоформ, препараты серебра, перуанский бальзам, нафталан, этиловый спирт, салициловую кислоту, препараты свинца [28].

Русский патолог Ф.И. Пиотровский, в 1860 году написавший диссертацию «О гире и огневике», приоритетным в лечении гнойно-воспалительных заболеваний считал противовоспалительное лечение без хирургического вмешательства. Также, он полагал, что фурункулами чаще болеют лица, «живущие в бедности, или же старики полнокровные, страдающие подагрой», а также перенесшие травму кожи.

В 60-70 годах XIX века были достигнуты значительные успехи в области микробиологии. Это дало значительный толчок в развитии учения о пиодермиях.

В 1878 году опубликованы результаты экспериментов Р. Коха по культивированию стафилококка, возбудителя раневых инфекций, на основании микроскопического наблюдения описаны свойства микроорганизмов, выделенных из инфицированных ран [28].

В 1884 году Ф. Розенбах описал два типа пигментированных колоний стафилококков и предложил следующую номенклатуру: Staphylococcus aureus (золотистый), Staphylococcus albus (белый). Он установил, что стафилококк способен вызывать распад лейкоцитов [28, 29].
Т. Бильрот в 1874 году впервые обнаружил стрепотококки в тканях человека при рожистом воспалении и раневых инфекциях. Позже в 1879 году указанные микроорганизмы были обнаружены Л. Пастером, а в 1881 году А. Огстоном при септицемиях и гнойных поражениях [28].

Термин «пиодермиты» для наименований гнойничковых заболеваний кожи впервые в 1981 году предложил Ленуар [34].

В 1882 году один из основоположников отечественной дерматологии А.Г. Полотебнов для лечения вскрывшихся фурункулов использовал повязки с плесенью Penicillinum и Aspergilinum. Однако широкое применение пенициллинов произошло в конце 40-х годов XX века после его кристаллизации Э. Чейном, сотрудником А. Флеминга [28, 34, 36].

В «Очерках гнойной хирургии» А.Ф. Войно-Ясенецкий описал несколько клинических случаев осложненного течения фурункула и карбункула лица. Кроме того, он предложил достаточно радикальный способ хирургического лечения абсцедирующего фурункула и карбункула лица путем кругового вырезания их в пределах здоровых тканей, особенно при злокачественном течении [8].

На сегодняшний день проведено большое количество исследований, посвященных изучению этиологии и патогенеза гнойно-воспалительных процессов, в частности фурункула челюстно-лицевой области, постоянное совершенствуются методики лечения гнойно-воспалительных заболеваний. Интерес ученых к этой проблеме не утрачен. Это объясняется значимыми изменениями в клиническом течении фурункула лица, проявляющимися в виде атипичных инкурабельных форм, повышающих риск развития угрожающих жизни состояний и имеющих тенденцию к хроническому течению.

Длительное время ведущую роль в развитии фурункула лица отдавали бактериальному агенту. На коже здорового человека, в волосяных фолликулах, протоках сальных и потовых желез присутствуют аэробные и анаэробные микроорганизмы; грамположительные (стафилококки, стрептококки, микрококки, пропионобактерии, коринеформные бактерии) и грамотрицательные (кишечная палочка, протей) бактерии, дрожжеподобные грибы родов Candida u Malassezia, плесневые грибы. Нормальную микрофлору кожи подразделяют на резидентную и транзиторную. В состав резидентной микрофлоры входят Staphylococcus epidermidis, Micrococcus spp., Sarcina spp., Propionibacterium spp., коринеформные бактерии и др. К транзиторной микрофлоре кожи относятся Streptococcus spp., Peptococcus spp., Bacillus subtilis, Escherichia coli, Enterobacter 
spp., Acinetobacter spp., Lactobacillus spp., Candida albicans и др. [21, 28, 34].

Основным возбудителем фурункула челюстно-лицевой области является золотистый (в 95\%), реже белый стафиллококк. Чаще они высеиваются в виде монокультуры, реже в ассоциации с другими микроорганизмами, такими как E. coli, Str. Haemoliticus, Str. Epidermidis [5, $17,26,27,28,29]$. Известно, что в состав нормальной микрофлоры кожи человека входят условно-патогенные микроорганизмы, сапрофитная флора. Так, у здоровых лиц стрептококки и стафилококки обнаруживаются в среднем до $10 \%$ случаев. В.Г. Арзуманян и соавторы приводят данные об обсемененности кожи здоровых людей и лиц с различными кожными заболеваниями. Выявлено, что в подавляющем большинстве случаев при различных заболеваниях кожи высевается Staph. aureus (до 89\% случаев), реже обнаруживаются Str. haemolyticus u Staph., epidermidis[28]. По данным Ю.Н. Кошевенко (год), на коже здорового человека сапрофиты составляют 49,5\%, условно-патогенные микроорганизмы $-41,8 \%$ и патогенные $-8,7 \%$ [21].

Безусловно, бактерии играют одну из ключевых позиций в развитии фурункула лица. Однако, все большее число исследователей приходят к выводу, что бактерии не являются непосредственной причиной заболевания, они лишь провоцируют местные воспалительные процессы. Для возникновения пиодермии очень важно наличие общих и местных предрасполагающих факторов.

Так, М.Н. Зубков выделяет две группы факторов, способствующих развитию глубоких пиодермий [20]. К первой группе относятся факторы, связанные с состоянием кожи:

1. Нарушение целостности кожного покрова;

2. Загрязнения кожи, чаще всего на лице, шее, кистях;

3. Несоблюдение правил личной гигиены - недостаточно частое и своевременное мытье кожи способствует накоплению на ней пыли и грязи, разрыхлению рогового слоя и размножению гноеродных микробов;

4. Мацерация кожи;

5. Раздражение кожи химическими веществами;

6. Перегревание и переохлаждение кожи, влекущее за собой количественные изменения потоотделения, нарушения кровообращения и трофики кожи, понижение ее сопротивляемости и возникновению гнойничковых заболеваний.

К внутренним факторам относят:

1. Заболевания внутренних органов, возникающие у ослабленных пациентов, перенесших инфекционное заболевание, страдающих хроническими заболеваниями желудочно-кишечного тракта, нарушениями обмена веществ, особенно углеводного;

2. Пониженное питание, гипо- и авитаминозы;

3. Функциональные нарушении нервной системы, нервное и психическое переутомление;

4. Возрастные особенности кожи.

По данным литературы ведущей местной причиной является снижение барьерной функции кожного покрова. Нарушение целостности эпидермиса может произойти при ссадине, порезе во время бритья, мацерации кожи, при получении различных микротравм [6, 14, 17, $20,41]$. Кроме того, на барьерную функцию кожи влияет pH кожи и секрет потовых и сальных желез, которые обуславливают бактерицидную функцию кожи. При повышенной себосекреции и смещении $\mathrm{pH}$ кожи в щелочную сторону, увеличивается проницаемость эпителия фолликулов. В результате чего создаются благоприятные условия для роста патогенных микроорганизмов на поверхности кожи и внутри фолликулов, их проникновения в толщу эпидермиса и инфицирования окружающих тканей [18, 21].

Среди местных факторов также стоит указать загрязнение кожи, несоблюдение правил личной гигиены. Редкое мытье кожи способствует накоплению на ней пыли и грязи, разрыхлению рогового слоя и размножению гноеродных микробов $[14,17,20,35,41]$.

К общим факторам относятся: наличие сопутствующей патологии (заболевания эндокринной системы, желудочно-кишечного тракта, нарушениями обмена веществ, особенно углеводного), пониженное и несбалансированное питание, гипо- и авитаминозы, нервное и физическое переутомление, неблагоприятные метеорологические условия, а также охлаждение и перегревание организма. Под влиянием выше указанных факторов защитные и адаптационные механизмы организма находятся в постоянном напряжении, происходит их истощение, что в свою очередь приводит к развитию заболеваний, в том числе кожных пиодермий $[6,14,17,20$, $31,36,41]$.

Что касается военнослужащих, то помимо указанных факторов стоит обратить внимание особенности воинской службы.

Как известно, служба в рядах Вооруженных Сил страны по призыву сопряжена с напряжением адаптационного потенциала организма, особенно в ее начальный период. Попадая в распоряжение войсковой части, молодые воины вынуждены максимально задействовать адаптивные механизмы для эффективного функционирования в новых условиях проживания. По данным 
Вязницкого А.В. наиболее напряженным является первые полгода, когда идет процесс адаптации к службе (биологической, профессиональной, психологической и социальной) [1]. В этот период происходит снижение естественной резистентности организма, проявляющееся ростом уровня заболеваемости по первичной обращаемости инфекционной, органов дыхания, кожи и подкожной клетчатки, органов пищеварения [3, 30, 32].

По мнению Быкова В.Ю. и Устинова М.В. болезни кожи и подкожной клетчатки у военнослужащих обусловливаются отсутствием необходимых условий для соблюдения правил личной гигиены и оказания первой медицинской помощи при микротравмах, недостатками в организации размещения и банно-прачечного обслуживания личного состава, низким уровнем гигиенического воспитания и пропаганды здорового образа жизни [7].

Стоит обратить внимание и на специфический фактор прохождения воинской службы. Исследования показывают, что у солдат, по сравнению с юношами, находящимися на так называемой «гражданке», выявляются более высокие показатели депрессии и более низкие значения психосоциального благополучия. Это связано с тем, что начальный период службы характеризуется для солдат временным разрывом эмоционально близких отношений со значимым окружением (семья, друзья) и вынужденной утратой привычной психологически комфортной атмосферы. В контексте межличностного взаимодействия призывникам необходимо развивать и совершенствовать навыки конструктивного поведения в конфликтных ситуациях и коммуникативной компетентности [15].

Статистические данные последних лет свидетельствуют о том, что фурункул лица преимущественно развивается у лиц юного и молодого возраста $[6,14,17,41]$. По данным Файзуллиной Г.А. это наиболее частая форма воспалительных заболеваний, которая встречается у $80 \%$ молодых пациентов в возрасте до 25-30 лет [37, 38].

По данным Климовой И.С. (2009), чаще глубокие пиодермии развиваются в раннем репродуктивном периоде и периоде пубертата, т.е. в возрасте 19-35 лет (47,3\%) и 14-18 лет (32,7\%) соответственно. Начиная с позднего репродуктивного периода (36-45 лет) и до периода постменопаузы (56 лет и старше) происходит постепенное уменьшение частоты развития фурункула $[5,6]$.

Супиев Т.К. отмечает значительные колебания в возрастном составе пациентов с фурункулами лица. По его данным, в юношеском возрасте чаще развиваются фурункулы (42\%). Среди пациентов средних лет и пожилых встречаются карбункул, чему способствуют сопутствующие соматические заболевания у больного $[36,46]$.

Баранова И.Д. приводит следующие данные: среди пациентов с фурункулами и карбункулами в 68,9\% случаев преобладают лица в возрасте 21-40 лет, в 15,1\%16-20 лет и в 15,1\% - старше 40 лет [2].

По данным Робустовой Т.Г. фурункул и карбункул лица в $81 \%$ случаев возникают повторно, в $43 \%$ - у лиц с гнойными заболеваниями кожи [31].

Большинство авторов указывают, что фурункулы одинаково часто встречаются как у мужчин, так и у женщин. В то же время некоторые исследователи считают, что преимущественно это заболевание наблюдается у мужчин $(67,3 \%)[36,49]$.

При изучении особенностей развития фурункула лица следует обратить внимание на сезонность проявления заболевания. По данным Супиева Т.К. пациенты с данной патологией преимущественно обращаются в летний, осенний и весенний периоды - 31,2\%, 30\% и 21,3\% соответственно. Лишь 17,5\% пациентов обращаются за медицинской помощью зимой [36]. Исследователи Климова И.С. и Ефимов Ю.В. так же указывают, что тяжелые формы фурункула лица встречаются весной и осенью - 71,2\%. По мнению авторов это связано с сезонными колебаниями температуры и характерным изменением иммунологического статуса организма в указанные времена года $[6,14]$.

Частота расположения фурункула лица в различных областях лица объясняется анатомическими особенностями строения и функционирования кожи. Наиболее характерной его локализацией являются участки кожи с густым расположением волосяных фолликулов и сальных желез, что наиболее характерно для участка частой локализации (в 20\% случаев) в щечной области. Далее, по частоте встречаемости следуют подбородочная область, верхняя губа и область носа (12-15\%). Реже фурункул встречается в скуловой, лобной, височной и подглазничной областях (3-5\%) $[6,14,17,41]$.

Пусковыми факторами в развитии фурункула чаще являются: переохлаждение - 22,5\%, травма (попытка выдавливания) первичных воспалительных элементов кожи (пустулы, угри) - 27,6\%, перенесенный стресс $10,2 \%$, неудовлетворительная гигиена кожи лица - 6,8\% $[6,14,17,41,43]$.

Механизм развития, клиника и течение пиодермий зависит не только от вида микроба, его патогенных, вирулентных и инвазивных свойств, но и от защитных сил макроорганизма, особенностей взаимодействия 
его с возбудителем. Существенное значение имеют нарушения нормального функционирования и взаимодействия различных звенев иммунной системы, нарушения углеводного обмена, эндокринные расстройства, заболевания желудочно-кишечного тракта и ряд других сопутствующих соматических патологий. У лиц с хроническим рецидивирующим фурункулезом соматическая патология встречается в 100\% случаев, преимущественно это заболевания желудочно-кишечного тракта $(97,1 \%)$, ЛОР-органов (36,4\%), и эндокринная патология, представленная в 5,8\% случаев сахарным диабетом и в 7,7\% - гиперандрогенемией $[6,16,20,45$, 46].

Кожа является крупнейшим специализированным органом человека. Она представляет собой своеобразную систему, тесно связанную с внутренней средой организма, и являющуюся экологической нишей для микро-

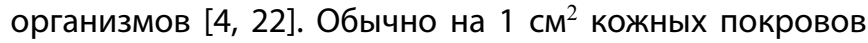
приходится $10^{3}-10^{4}$ микроорганизмов; на участках с повышенной влажностью их число может достигать $10^{6}$. Естественные механизмы, поддерживающие нормальный микробиоценоз здоровой кожи - это сами бактерии. Так, Staph. epidermidis выделяет токсины, обладающие антибиотикоподобным действием в отношении патогенной флоры, кроме того, Staph. albus угнетает Staph. Aureus $[6,34,48]$.

По данным различных авторов, у пациентов, страдающих фурункулом лица, имеют место нарушения микробиоценоза кожи. Так, микробный пейзаж кожи челюстно-лицевой области практически здоровых людей представлен непатогенными стафилококками - Staph. epidermidis (92,4\%) и Staph. saprophyticus (44,6\%), в 30\% случаев встречаются Str. haemolyticus ү и грибы рода Candida $[4,6,22,27,43,46]$.

У пациентов, страдающих фурункулом челюстно-лицевой области, микрофлора кожи лица представлена Staph. epidermidis (63\%), Staph. saprophyticus (30\%), Staph. aureus (2\%), грибами рода Candida (3\%), Str. haemolyticus ү и E. coli (1\%). Дрожжеподобные грибы, энтеробактерии и кишечная палочка на коже обычно не выявляются, только с возрастом, когда механизмы естественной защиты ослабевают, они появляются в сообществе микроорганизмов кожи [5, 20, 27, 43, 45, 49].

В результате данных изменений нарушается нормальное функционирование микрофлоры, развивается дисбактериоз кожи. При этом полиненасыщенные жирные кислоты (линолевая, линоленовая) могут трансформироваться в насыщенные, что становится причиной или сопутствующим фактором дисбаланса липидного обмена кожи, либо организма в целом.
Состав микрофлоры и размножение ее представителей контролируется самим организмом с помощью механических, бактерицидных, химических факторов $[47,48,49]$. К числу факторов, существенно влияющих на удаление транзиторной флоры с поверхности кожи, относятся кислая реакция среды (рH 4-5), наличие жирных кислот в секретах сальных желез, состояние кератинизации, присутствие лизоцима, трансферрина [23].

Изменение количества и состава кожного сала является одним из ключевых моментов в развитии фурункула челюстно-лицевой области. Секреторная активность сальных желез находится под контролем половых стероидом. По данным литературы к 18-25 годам уровень половых стероидов достигает максимальных значений [18, $21,34]$. В этот период повышается их влияние на клетки мишени волосяных фолликулов и сальных желез, что приводит к повышенной секреции сальных желез и изменению состава кожного сала. Так, повышение концентрации в составе кожного сала сапиената и себалеата приводит к развитию асептического воспаления. Линолевая и линоленовая кислоты входят в состав ацилцерамидов, которые играют роль своеобразных «заклепок» в многослойных липидных пластах межклеточного пространства, обеспечивающих сцепление корнеоцитов. При недостатке ацилцерамидов наблюдается расслоение мембраноподобных структур, нарушается не только проницаемость рогового слоя, но и нормальная дифференцировка кератиноцитов. Кроме того, снижение количества линоленовой кислоты приводит к смещению pH кожного сала в щелочную сторону, увеличению проницаемости фолликулярного эпителия. Указанные факторы содействуют нарушению барьерной функции эпителия и созданию условий для роста микроорганизмов на поверхности кожи и внутри волосяного фолликула [34].

Приводятся данные о влиянии различных гормонов на иммунную систему организма. У пациентов пубертатного и раннего репродуктивного периодов, страдающих фурункулом лица, отмечено повышенное содержание свободного тестостерона в сыворотке крови на фоне снижения концентрации эстрадиола и глобулина, связывающего половые стероиды [5]. Под действием тестостерона существенно снижается миграция В-клеток из костного мозга в селезенку, изменяется направление дифференцировки полипотентных клеток в сторону эритропоэза, в ущерб лимфопоэзу $[5,6]$.

Эстрогены, наоборот, избирательно активизируют отдельные клеточные популяции, участвующие в реализации иммунного ответа, стимулируют фагоцитарную способность макрофагов. Нарушение баланса андрогены-эстрогены в сторону первых, сопровождается изменениями в иммунной системе, заключающимися в сни- 
жении количества Т-лимфоцитов и их субпопуляций [6, $26,45]$

Наиболее существенными являются изменения в фагоцитарном и гуморальном звеньях иммунной системы. Особенно важно исследовать указанные показатели у пациентов с хронических рецидивирующим фурункулезом. Изучая особенности рецидивирующего фурункулеза Laube S.И., Farrell A.M. отмечают наличие аллергического компонента в воспалении при фурункулезе у лиц старшего возраста, что сопровождается повышением общего Ig E [46]. Дружинина Т.А. и Алексеев Н.Ю. установили, что у значительной части пациентов с повышенными значениями уровня сывороточного Ig Е течение фурункулеза характеризовалось формированием стойкого непрерывного рецидивирующего хронического гнойно-воспалительного процесса с множественными фурункулами и слабой воспалительной реакцией. Кроме того, авторами доказано, что у пациентов с хроническим рецидивирующим фурункулезом с повышенными значениями Ig Е наблюдается снижение оксидантного потенциала нейтрофилов, что может служить одной из причин формирования стойкого непрерывного рецидивирующего хронического гнойно-воспалительного процесса [11].

Важно при изучении данного заболевания оценивать не только количество иммуноглобулинов, но и их функциональную активность. Так, Сетдиковой Н.X и соавт. было установлено, что причиной рецидивирования фурункулеза является снижение аффиности иммуноглобулинов к общей антигенной детерминанте $S$. aureus, который является основным возбудителем фурункула лица и преимущественно высеивается при бактериологическом исследовании у пациентов с хроническим рецидивирующим фурункулезом [33].

Ряд исследователей считают, что одной из причин хронизации воспалительного процесса являются нарушения в нейтрофильном звене $[19,45]$. Одним из предрасполагающих факторов к снижению бактерицидности нейтрофилом является гипоферремия. Недостаток сывороточного железа приводит к снижению активности ферментов нейтрофилов (таких, как миелоперроксидаза), определяющих их бактерициность $[19,44]$. Также к хронизации воспалительного процесса могут приводить такие дефекты нейтрофилов, как нарушение переваривающей функции нейтрофилов (т.е. завершенность фагоцитоза), дефицит глюкозо-6-фосфат дигидрогеназы (характеризуется нарушением продукции перекиси водорода и восприимчивостью к S. aureus, E. coli), дефицит миелопероксидазы (необходимая ля внутриклеточного уничтожения бактерий), дефицит адгезии лейкоцитов I типа - дефицит интегринов CD11/CD18 (нарушается хемотаксис гранулоцитов) [6, 19, 26, 44].
В последнее время многие авторы указывают контактный компонент в развитии рецидивирующего фурункула $[43,45,50]$. Особенно важно учитывать этот фактор, если пациенты являются членами одной семьи или общины, поскольку непосредственный физический контакт с носителями является основным фактором риска развития рецидивирующего фурункулеза. В этом случае следует избегать повторного использования или обмен личными вещами, такими как одноразовые электрические бритвы или эпиляторы, постельное белье или полотенца, которые были использованы на зараженной коже. Так, Winthrop K.L. et al. описали 110 клинических случаев с жителями Северной Каролины с хроническим рецидивирующим фурункулезом, которые пользовались услугами одного и того же педикюрного салона [51].

В последние годы исследователи уделяют пристальное внимание нарушению баланса про-антиоксидантных реакций организма при развитии гнойно-воспалительных процессов челюстно-лицевой области, поскольку это является одной из причин развития синдрома эндогенной интоксикации $[12,13,40,41,42]$.

Дурново Е.А. выделяет три компонента эндогенной интоксикации при хирургической инфекции: микробиологический, биохимический и иммунологический. Основным источником интоксикации являются продукты распада белков в виде разнообразных соединений с различной молекулярной массой, приобретающих свойства токсинов. Степень интоксикации бывает весьма различна и зависит от локализации и распространенности воспалительного процесса, характера микрофлоры, возраста больного и реактивности организма $[12,13]$.

Установлено, что истощение внутренних компенсаторных механизмов организма, уменьшение активности антиоксидантной системы, повышение концентрации продуктов перекисного окисления липидов (диеновые конъюгаты, малоновый альдегид) и других токсических субстанций в крови формирует эндогенную интоксикацию, степень которой напрямую связана с клиническим течением многих воспалительных заболеваний челюстно-лицевой области. Доказано, что нарушения в системе ПОЛ-АОЗ и высокий уровень эндогенной интоксикации снижают скорость репаративных процессов, продлевают стадию очищения гнойной раны и могут служить основанием к неблагоприятному исходу заболевания, развитию осложнений $[13,20,40,41]$.

Таким образом, фурункул лица, особенно его хронические формы, является полиэтиологичным заболеванием. Многими исследователями доказано, что в патогенезе развития указанного заболевания играют роль несколько взаимосвязанных между собой факторов, о чем следует помнить при выборе тактики лечения. 


\section{ЛИТЕРАТУРА}

1. Адаптация молодого воина к условиям службы и профилактика диза-даптационных расстройств. Методическое руководство / А.В. Вязницкий и др. -М., 1990.-28c.

2. Баранова И.Д. Новые подходы к лечению хронического фурункулеза с помощью современных иммуномодуляторов: автореф. дис. ... канд. мед. наук: 14.00.36 / И.Д. Баранова.— М., 1999. - 22 с.

3. Басалыга, В.Н. Гигиеническое обоснование мероприятий по неспецифической профилактике болезней органов дыхания в организованных воинских коллективах: автореф. канд. мед. наук: 14.00 .07 / Басалыга Василий Николаевич Н. Новгород, 2003. - 20 c.

4. Бондаренко В.М., Боев Б.В., Лыкова Е.А., Воробьев А.А. Дисбактериозы желудочно-кишечного тракта // Российский журнал гастроэнтерологии, гепатологии, колопрактологии.- 1998. - №1.- С. 66-70.

5. Бородулина И.И. Микробный пейзаж при фурункуле лица / И.И. Бородулина, И.С. Климова, Е.А.Железнова // Забайкальский медицинский вестник.-2009. — № 2.—C. 22-24.

6. Бородулина И.И. Фурункул и карбункул челюстно-лицевой области: учебное пособие/ И.И. Бородулина, И.С. Климова. — Чита.: РИЦ ЧГМА, 2011. — 67 с.

7. Быков И.Ю. 0 проведении эксперимента по снижению заболеваемости дерматовенерологического профиля военнослужащих Северо-Кавказского военного округа /И. Ю. Быков, А.В. Самцов, В.В. Гладько, М.В. Устинов// Военно-медицинский журнал.— 2006. — № 2(327) -С.4-8.

8. Войно-Ясенецкий, Валентин Феликсович (1877-1961). Очерки гнойной хирургии [Текст] / Святитель Лука (В.Ф. Войно-Ясенецкий). - 6-е изд.- - Симферополь: издание Симферопольской и Крымской епархии, 2016. - 511 с.

9. Гайворонская Т.В. Динамика состояния антиоксидантной активности плазмы крови у больных одонтогенными флегмонами челюстно-лицевой области при комплексном лечении // Российский стоматологический журнал. — 2008. — № 1.— С. 30-31.

10. Григорьев С.Г. Медико-статистическая характеристика заболеваемости военнослужащих по призыву Вооруженных Сил Российской Федерации (20072016 гг.)/ С.Г. Григорьев, В.И. Евдокимов, В.В. Иванов, П.П. Сиващенко, Д.И. Фефелов// Воен.-мед.журн.-2017. № 10 (338): С. 4-14.

11. Дружинина Т.А. Сравнительная оценка течения хронического рецидивирующего фурункулеза и фагоцитарного звена иммунитета в группах больных с различным уровнем сывороточного иммуноглобулина Е/ Дружинина Т.А., Алексеева Н.Ю.// Медицинская иммунология. — 2014. — Т. 16. — № 3.— стр.295-300.

12. Дурново Е.А. Развитие синдрома эндогенной интоксикации у больных с острыми гнойно-воспалительными заболеваниями челюстно-лицевой области и шеи: учеб. пособие / Е.А. Дурново.— Н. Новгород, 2000. - 25 с.

13. Дурново Е.А. Роль свободнорадикального окисления в патогенезе воспалительных заболеваний челюстно-лицевой области // Матер. ХІ Международной конференции челюстно-лицевых хирургов и стоматологов. - СПб., 2004.- С. 67-68.

14. Ефимов Ю.В. Фурункулы и карбункулы челюстно-лицевой области: учебное пособие/ Ю.В. Ефимов, Х.Х. Мухаев, Е.Н. Ярыгина, В.Н. Мухин — М.: Медицинская книга, 2012. - 48с.

15. Заворотный В.И расуицидального поведения среди солдат срочной службы // Тюменский медицинский журнал. 2013. Т. 15, № 1. С. 7-8.

16. Имбряков К.В. Сравнение заболеваемости и тактики лечения больных с фурункулами и карбункулами лица по данным Самарской и Кировской областей/ К.В. Имбиряков, В.Ю. Никольский // Российский стоматологический журнал.— 2013.— № 5.— С. $27-29$.

17. Имбряков К.В. Фурункулы и карбункулы лица/ К.В. Имбиряков, В.Ю. Никольский // Российский стоматологический журнал. 2013. № 5. С. 52-56.

18. Кабаева Т.И. Роль состава кожного сала в патогенезе акне / Т.И. Кабаева, Г.А. Осипов // Вестн. дерматол. венерол.— 2004.— № 2.— С. 28-30

19. Калинина Н.М. Нарушения иммунитета при рецидивирующем фурункулезе// Цитокины и воспаление. — 2003.-Т.2. — № 3. — стр.41-44.

20. Касенова Н.С. Этиопатогенез и частота развития фурункулов и карбункулов челюстно-лицевой области//Здравоохранение Кыргыстана.-2012.— № 3. C. 97-102.

21. Кошевенко Ю.Н. Кожа человека: руководство для врачей и студентов/ Ю.Н. Кошевенко.— М.: Медицина, 2007. — Т. 1. — 360 с.

22. Крамарь В.С. Пространственная структурная иерархия микроорганизмов в биоценозе кожи // Вестник Волгоградского государственного медицинского университета.—- Волгоград, 2003.- Т. 58. Вып.9.—С. 23-27.

23. Лисишникова Л.П. Особенности микробиоценоза основных биотопов организма человека в условиях Европейского Севера России: автореф. дис. .... канд. биол. наук.- Архангельск, 1997.- 25 с.

24. Монахов С.А. Антиандрогенная терапия акне у женщин / С.А. Монахов, 0.Л. Иванов, М.А. Самгин // Рос. журн. кож. венер. 60л. — 2005.— № 3.— С. 66-70.

25. Мухаметжанов А.М. Заболеваемость военнослужащих срочной службы/ А.М. Мухаметжанов, Н.К. Смагулов // Медицина труда и промышленная экология.-2015.-№ 3.- С. 22-25.

26. Новикова И.А. Показатели иммунного статуса у больных хроническим рецидивирующим фурункулезом в стадии ремиссии/ Новикова И.А., Гомоляко А.В. // Медицинская иммунология. — 2010.-Т.12.-№ 3. — стр.241-246.

27. Оценка стафилококковой и нелипофильной дрожжевой микрофлоры кожи у больных с патологией при контактном способе посева / В.Г. Арзуманян [и др.] // Вестн. дерматол. венерол.- 2004. -№ 6.- С. 3-6.

28. Пиодермии: учеб. пособие для осваивающих образовательные программы высшего образования по специальности «Лечебное дело» / под ред. С.А. Чернядьева, М.А. Уфимцевой//Уральский гос. мед. университет — Екатеринбург: Издательство УГмУ, 2016-104 с.

29. Потатуркина-Нестерова Н.И. Микробиота кожи в норме и при патологии / Н.И. Потатуркина-Нестерова, О.Е. Фалова, И.С. Немова, Н.С. Онищенко; под ред. Н.И. Потатуркиной-Нестеровой. - Ульяновск: УлГТУ, 2014.— 113 с. 
30. Потехина, Н.Н. Научное обоснование системы нутриционной профилактики заболеваний, связанных со снижением естественной резистентности организма военнослужащих: автореф. докт. мед. наук: 14.00.07 / Потехина Наталья Николаевна. М., 2004. — 45 с.

31. Пути профилактики и лечения распространенных воспалительных заболеваний челюстно-лицевой области и их осложнений / Т.Г. Робустова [и др.] // Клин, стоматол. - 1995.- № 1.- С. 31-33.

32. Сгибнев, Д.В. Новый способ профилактики внебольничных пневмоний в воинских коллективах: автореф. . канд. мед. наук: 14.00.30;14.00.07 / Сгибнев Дмитрий Викторович. Н. Новгород, 2004. - 24 с.

33. Сетдикова Н.Х. Комплексные механизмы развития хронического рецидивирующего фурункулеза и пути их коррекции / Н.Х. Сетдикова, Т.В. Латышева // Иммунология. - 2000.— №3.- С. 48-50.

34. Соколовский Е.В. Кожные и венерические болезни: учебное пособие для студентов медицинских ВУЗов. — Спб.: Фолиант, 2008. — 520 с

35. Соловьев М.М. Гнойно-воспалительные заболевания головы и шеи. Этиология, патогенез, клиника, лечение. / Под ред. М.М. Соловьева, 0.П. Большакова, Д.В. Галецкого - М.: МЕДпресс-информ, 2016. - 192 с.

36. Супиев Т.К. Гнойно-воспалительные заболевания челюстно-лицевой области / Т.К. Супиев.— М.: Медпресс.-2001.—C.160.

37. Файзуллина Г.А. Особенности микрофлоры раневого отделяемого при фурункулезе челюстно-лицевой области / Г.А. Файзуллина, А.Р. Мавзютов // Инфекционные болезни. - 2010.— № 1.- С. 335-336.

38. Файзуллина, Г.А. Этиопатогенетические особенности фурункула челюстно-лицевой области/ Г.А. Файзуллина, Ф.3. Мирсаева // Медицинский вестник Северного Кавказа. - 2018. - № 1-1(13).- С. 38-41.

39. Флерьянович М.С. Морфология гнойной раны у экспериментальных животных с моделью фурункула в поднижнечелюстной области / М.С. Флерьянович, И.0. Походенько-Чудакова, Е.Л. Колб// Вестник ВГМУ.-2015.— № 4(14).—C. 106-111.

40. Фомичев Е.В. Клинико-лабораторная диагностика эндогенной интоксикации у больных вялотекущими и хроническими гнойно-воспалительными заболеваниями челюстно-лицевой области// Вестник ВолГМУ.— 2010.— № 1 (33).— С. 99-102.

41. Химич И.В. Фурункулы, карбункулы, рожистое воспаление лица: учебно-методическое пособие/ И.В. Химич, В.В. Подольский, Т.С. Есикова, В.С. Хлыбов Волгоград: Издательство ВолГМУ, 2011.-68 с.

42. Щербакова 0.А. Комплексная терапия больных хроническим рецидивирующим фурункулезом с нарушением аффинности иммуноглобулинов: автореф. дис. ... канд. мед. наук: 14.00.36 / 0.А. Щербакова. - М., 2004. - 26 с.

43. Bernard P. Management of common bacterial infections of the skin / P. Bernard //Ann. Dermatol. Venerol._ 2008. -V ol. 135, No I. — P. 13-19.

44. Demirzay Z. Phagocytosis and oxidative burst by neutrophils in patient with recurrent furunculosis/ Demirzay Z., Noyoya A.M., Fereia de Carvalho F., Bruno S. // Brit. J. Dermatol. — 1998. — Vol.138, № 6.—P. 1036-1038.

45. Ibler K.S. Reccurent furunculosis-challenges and management: a review/ Ibler K.S., Kromann C.B.// Clinical, Cosmetic and Investigational Dermatoligy.- - 2014.№ 7.- $-59-64$.

46. Laube S., Farrell A.M. Bacterial skin infections in the eldery: diagnosis and treatment// Drugs Aging. — 2002. — Vol.19, № 5. — P. 331-342.

47. Lowbury E. Topical Antibacterials: Perspectives and Issues. In: Skin Microbiology, Relevance to Clinical Infection. Eds. H. Maibach. R. Aly. New York: Springer-Verlag, 1981. - P. 158-168.

48. Lowy F., Hammer S. Staphylococcus epidermidis infection // Ann. Intern. Med. — 1983. — V.99, № 6. — P. 834-839.

49. Rosenbury T. Microorganismus indigenous to man. - N.Y.: McGraw Hill, 1966. - 203 p.

50. Trent J.T. Common bacterial skin infections / J.T. Trent, D. Federman, R.S. Kirsner // Ostomy Wound Manage. — 2001.— Vol. 47, № 8. — P. 30-34.

51. Winthrop K.L., An outbreak of mycobacterial furunculosis associated with footbaths at a nail salon / Winthrop K.L., Abrams M., Yakrus M. et al. // New Engl. J. Med. 2002.—Vol. 346. № 18.—P 1366-1371.

() Петрова Татьяна Вячеславовна ( tanya-petrova-1995@yandex.ru ),

Бородулина Ирина Ивановна ( borodulina59@mail.ru ),Тегза Николай Васильевич ( tegza75@mail.ru).

Журнал «Современная наука: актуальные проблемы теории и практики» 